\title{
Value relevance of realized gains and losses on available-for-sale securities
}

\author{
Retno Yulianti \\ Department of Accounting, Faculty of Economics and Business, \\ Universitas Pembangunan Nasional "Veteran" Yogyakarta, \\ Indonesia \\ Doctorate Program of Economics Science, Faculty of Economics and \\ Business, Universitas Sebelas Maret, Indonesia \\ retno.yulianti@,upnyk.ac.id
}

Ari Kuncara Widagdo

Department of Accounting, Faculty of Economics and Business,

Universitas Sebelas Maret, Indonesia

widagdo1998@,staff.uns.ac.id

\section{Doddy Setiawan}

Department of Accounting, Faculty of Economics and Business,

Universitas Sebelas Maret, Indonesia

doddy.setiawan@staff.uns.ac.id

\section{Bambang Sutopo}

Department of Accounting, Faculty of Economics and Business,

Universitas Sebelas Maret, Indonesia

bsutopo@staff.uns.ac.id

Abstract. Several studies reveal that net income has high value relevance, but once AFS securities gains and losses are realized, such a realization will affect the amount of net income reported. The purpose of this study is to investigate the effect of realized AFS securities gains and losses on firm value (FV). The present study used quarterly financial statements of banks listed at the Indonesia Stock Exchange from 2011 to 2017 and multiple regression analysis. The results of this study reveal that realized gains and losses on AFS securities have a negative effect on firm value, which means that realized gains and losses on AFS securities have value relevance. These findings imply that users of financial statements have considered realized gains and losses on AFS securities when they get information about net income.

Keywords: value relevance, firm value, available-for-sale securities, other comprehensive income, Indonesia. 
JEL Classification: G21, M41

\section{INTRODUCTION}

Several studies report banks expanding into non-interest income activities run a higher risk than banks which mainly supply loans (De Young \& Roland, 2001; Lepetit, Nys, Rous, \& Tarazi, 2008). Such a high risk results from very volatile income derived from the activities that do not constitute the primary objective of bank operations. Revenue from a bank's traditional lending activities tends to be stable over time because switching costs and information costs make it costly for either debtor or creditor to end the lending relationship (DeYoung \& Roland, 2001). Steady interest income coupled with fluctuating non-interest income result in fluctuating net income. Such a condition will increase risks.

Financial statements prepared by Indonesian banks classify income into three: interest income, other operating income, and non-operating income. Realized gains and losses on AFS securities are non-interest income listed as a component of other operating income. In presentation of comprehensive income pursuant to the Institute of Indonesian Chartered Accountants' statement of financial accounting standard (Pernyataan Standar Akuntansi Kenangan), abbreviated as PSAK, No. 1 (2009) adopting IAS No.1 as of 2009 (Ikatan Akuntan Indonesia/IAI, 2012), coming into effect during the financial year starting as of 1 January 2011 or afterwards, unrealized gains and losses on AFS securities are presented in other comprehensive income (OCI). These gains and losses are only recognized in net income when they are realized, i.e., when the security is sold or otherwise disposed of, or when impairment is deemed other-than-temporary (Barth, Gomez-Biscarri, Kasznik, \& López-Espinosa, 2017). Such gains and losses will be presented as other operating income, which will affect the amount of net income reported.

Empirically, net income is more attractive than any other income components in the statements of comprehensive income (Dhaliwal, Subramanyam, \& Trezevant, 1999; Biddle \& Choi, 2006; Kabir \& Laswad, 2011). Nevertheless, the development of research into value relevance of figures in financial statements indicates value relevance of OCI. In many countries, total other comprehensive income has higher value relevance than net income (Lin, Ramond, \& Casta, 2007). Two components of other comprehensive income, which are an adjustment to foreign currency translation and unrealized AFS securities gains and losses, even have higher value relevance than that of any other components (Chambers, Linsmeier, Shakespeare, \& Sougiannis, 2007). Yousefinejad, Ahmad, \& Embong (2017) and Boulland, Lobo, \& Paugam (2019) secure the evidence on the value relevance of unrealized AFS securities gains and losses. Like with unrealized securities gains and losses, the relevance of realized securities gains and losses had also been proven by Warfield \& Linsmeier (1992) and Ahmed \& Takeda (1995). However, they did not specifically examine the value relevance of realized gains and losses on AFS securities. Instead, they conducted a study on securities in general, which included trading securities, AFS securities, and held-tomaturity securities. Thus, there is only limited evidence of the value relevance of change in unrealized gains and losses on AFS securities as an OCI component into realized ones in net income. This research aims to examine the effect of realized gains and losses on AFS securities upon firm value. It is imperative to conduct this study as in the presentation of comprehensive income, realized gains and losses on AFS securities might determine the amount of net income to be reported.

AFS securities are any non-derivative financial assets designated on initial recognition as available for sale or any other instruments that are not classified as (a) loans and receivables, (b) held-to-maturity investments or (c) financial assets at fair value through profit or loss (PSAK 55/ IAS 39). Unlike trading securities, the differential between AFS securities' fair value and acquisition price recognized as unrealized gains or losses is listed in OCI. If those securities are sold or otherwise disposed of, or when impairment is deemed other than temporary, the resulting gains or losses will only be recognized in net income. Such a 
difference in presentation occurs as an income statement contains information about a company's future economic prospects. Since the ownership of trading securities generally aims to gain profits from shortterm price fluctuations or trader's margin (PSAK 55 on Application Guideline 27), the gains or losses are more definite than AFS securities. Thus, unrealized gains or losses on marketable securities are presented as a component to be subtracted from or added to net income.

Firm value refers to a company's operating value or rate of return that is expected to provide all claim holders with yields (Penman, 2013). This definition of firm value is in practice, usually referred to as the intrinsic value. Stock market prices try to reflect firm value because stock prices are determined based on the valuation stock market players make of a company's business potential. The assessment generates the so-called intrinsic value, which is then compared with the market value to make an offer. The input used to determine an intrinsic value might be dividends, cash flows, and earnings (Penman, 2013). There are various components of earnings reported in financial statements, one of which is net income.

The research conducted by Jaggi \& Zhao (2002) indicated the possibility of the market responding to realized gains and losses on AFS securities. They studied the effect from the change of SFAS 12 to SFAS 115 in 1993 on the classification of available-for-sale financial assets and found out that information related to the components of earnings is more relevant to investment-related decision-making after the implementation of SFAS 115 and that unrealized gains or losses provide additional information after being disclosed in detail in accordance with SFAS 115. If unrealized gains or losses provide additional information, there should be a strong likelihood that realized gains or losses determine firm value as they may affect the amount of net income reported.

Unusual activities in a company's operations often catch the attention of users of financial statements. Likewise, the realization of AFS securities gains and losses possibly attracts the attention of such users, in this case investors, which, in turn, may affect their valuation of a firm. Realization of AFS securities gains and losses are worth researching as those gains and losses correlate with non-interest income of banks. This income is a diversification for the banks in performing their non-core business. Diversification can yield profits for banks, yet may also pose risk to their performance (Bian \& Wang, 2015). Previous studies examined the value relevance of realized gains and losses on banks' investment securities (Warfield \& Linsmeier, 1992; Barth, 1994; Ahmed \& Takeda, 1995) and value relevance of unrealized gains and losses on AFS securities (Chambers et al., 2007; Yousefinejad, Ahmad, \& Embong, 2017; Boulland, Lobo, \& Paugam, 2019). This research takes on different ground, with the purpose of studying value relevance of realized gains and losses on AFS securities as the contribution.

The remainder of this paper is structured as follows. First goes the review of the related literature and hypothesis development on the associations between realized AFS securities gains and losses and firm value. This is followed by the research method. Then, the empirical results, robustness tests, and discussion are presented. Lastly, conclusions, the limitations of our study, and further research directions are elaborated.

\section{LITERATURE REVIEW}

\subsection{Comprehensive income}

Comprehensive income is defined as a broad measure of the effect of transactions and other events on an entity, consisting of any change recognized in equity (net assets) of an entity for one period of transactions, events, and conditions other than the ones derived from owner investment and distribution to owners (Financial Accounting Standard Board, 1984). Comprehensive income breaks earnings down into several components of earnings and other comprehensive income can improve the understanding of an entity's financial performance and provide information that helps investors and creditors better understand 
changes in equity ownership and the company's ability to produce future cash flows (Casabona \& Conville, 2014). As implications of the concept of comprehensive income, FASB issued SFAS No. 130 in 1997, which stipulates the presentation of comprehensive income. There are changes to rules about the presentation of comprehensive income. Initially, there were three options to present comprehensive income, i.e. 1) to report the total comprehensive income for one period, and OCI as well, under total net income in single consolidated statements of income and comprehensive income, 2) to report it in separate statements of comprehensive income starting with net income, and 3) to report it in statements of shareholders equity (Accounting Standard Codification/ASC 220-45-8 in Casabona \& Conville, 2014). Furthermore, Accounting Standard Update (ASU) 2011-05 (Financial Accounting Standard Board, 2011) removed the option of presenting OCI in equity change statements, leaving only two options, namely: a single continuous statement of comprehensive income and two separate but consecutive statements. Similarly, Indonesia, through PSAK No. 1 of 2009, offers those two presentation options.

The benefits of comprehensive income can be seen from two perspectives: investors usefulness and contracting usefulness (Black, 2016). In connection with the first view, Hirst \& Hopkins (1998) prove that clear disclosure of income statements as to comprehensive income and its components can effectively increase the transparency of corporate earnings management activities and reduce judgment in the assessment made by an analyst(s). Maines \& McDaniel (2000) support this finding as well. They find out that participants attach considerable weight on their volatility assessment when unrealized gains or losses are present in the statements of comprehensive income according to SFAS 130. However, Chambers et al. (2007) prove otherwise, i.e., that investors will recognize OCI when it is reported on the statement of equity change as OCI reported in equity change is more familiar for them.

\subsection{Decision usefulness and measurement approaches}

Reporting rational information that investors need for decision-making purposes is called a decision usefulness approach (Scott, 2015). Accountants use it in financial statements in response to the impossibility of presenting theoretically correct financial statements. The decision usefulness information approach emphasizes reliability because this approach views that historical cost-based reporting is acceptable as long as it provides as much information as possible. With full disclosure, it is expected that financial statements will have relevance to decision-making.

In addition to the decision usefulness approach, there is another approach, i.e., measurement, which is an approach to financial reporting where accountants are responsible for reporting the present value in financial statements as reliably as possible to help investors predict a company's present value and performance (Scott, 2015). The reasons for switching to the measurement approach are: a) the capital market may not be fully efficient, and efficiency is a matter of to what extent it exists, rather than whether or not it is present, and b) the low proportion of stock prices explained by net income based on historical costs (Scott, 2015). Despite an emphasis on relevance, the measurement approach has limited reliability to assess the present value.

Not all research findings suggest investors' greater interest in earnings-related information. Lev and Zarowin (1999) indicate that income has decreased value relevance. Income's low-value relevance encourages a switch to the measurement approach. Feltham \& Ohlson (1995) developed the clean surplus theory, which describes the measurement approach by explaining the ways the balance sheet and components of the statements of profit or loss indicate the market value of a company.

Since the introduction of the measurement approach, numerous research into income relevance leads to a comparison of the relevance of each component of earnings in the statements of comprehensive income. Jaggi \& Zhao (2002) studied the effect of the change of SFAS 12 into SFAS 115 in 1993, which 
reclassified the presentation of investment securities for banking companies. Reclassifying securities is expected to reduce the management's discretion in classifying securities, reduce differences in unrealized gains or losses between companies, and eventually provide more information as to unrealized gains or losses. Their research findings reveal that information about the components of earnings are more relevant to investment-related decision-making after SFAS 115 comes into effect. In Indonesia, Mita, Siregar, \& Fitriany (2017) examined the value relevance of OCI and its components after the adoption of IAS 1 to the Indonesian Accounting Standard, PSAK No. 1 (2009). The result shows that OCI and its components have value relevance.

\subsection{Are realized AFS securities gains and losses a signal?}

A signal refers to an action undertaken by a high-type manager, but it will no longer be rational if done by a low-type manager (Scott, 2015). In accounting, there are a number of signals, which include the proportion of equity retained during the initial public offering (IPO) (Leland \& Pyle, 1977), audit quality (Titman \& Trueman, 1986), forecast (Vermaelen, 1981; Hartnett, 2010), dividend policy (Tong \& Miao, 2011), and accounting policy (Morris, 1987). However, they are not always informed separately as they sometimes might be reported simultaneously with the others. Fan (2007) used two signals, which were reported earnings and ownership retention during IPO.

Accounting policies consist of the accrual policy and the real activity policy. In the latter, the policy as to $R \& D$ expenditures can be a signal. When $R \& D$ expenditures are charged when they occur, net income will reduce. However, such a decrease in net income will not trigger any negative market response as the market expects its future benefits. Therefore, R\&D expenditures will cause stock prices to rise (Aboody \& Lev, 1998). Hsiao, Liao, Su, \& Sung (2017) clarified that discretionary R\&D capitalization for target beating can be characterized as a firm signaling private information on its future economic benefits or as an opportunistic earnings management. Whereas, Dinh, Kang, \& Schultze (2016) elaborated that the correlation between R\&D capitalization and market values depends on the purpose of the capitalization itself, whether for benchmark beating or else. For the former purpose, R\&D capitalization is priced negatively. In other words, the greater the $\mathrm{R} \& \mathrm{D}$ capitalization, the lower the market value of the company as the market can detect opportunistic behavior related to R\&D accounting and discount firm values accordingly. Yet when reflecting no impact on beating a benchmark, R\&D capitalization correlates positively with firm value. Greater R\&D capitalization means less net income, yet triggering positive reaction of investor since investment on $\mathrm{R} \& \mathrm{D}$ is expected to gain economic benefit in the future.

Like R\&D expenditures, realized gains and losses on AFS securities are also real activities. Both realized gains and losses on AFS securities and R\&D expenditures are real activities with the same role, i.e., to reduce net income when a company realizes losses in the event of the sales or disposal or impairment of AFS securities. Considering the definition of signals above, are realized gains and losses on AFS securities a signal? A high-type manager might opt for realized AFS securities losses as banks derive their core operating income from interest income, thus informing losses on non-interest income will not cost much. Conversely, for low-type managers such an option is irrational as it will only worsen their already poor performance and be a bad signal for investors; thus they will opt for realizing gains. To conclude, realized gains and losses on AFS securities are signals.

\subsection{Hypothesis development}

Some researchers have proven the benefits of presenting components of earnings in comprehensive income. According to Jaggi and Zhao (2002), information about the components of earnings is more relevant to investment-related decision-making after SFAS 115 comes into effect. Furthermore, Chambers 
et al. (2007) demonstrated that two components of other comprehensive income, which are an adjustment to foreign currency translation and unrealized AFS securities gains and losses, have higher value relevance than that of any other components. Similarly, Lin, Ramond, \& Casta (2007) using a sample of various countries proved that OCI has value relevance higher than that of net income in many countries, but total comprehensive income is less relevant to the other two figures, which are operating income and net income. However, researches undertaken by Dhaliwal et al. (1999) and Doukakis (2010) do not support the use of comprehensive income statements. Dhaliwal et al. (1999) concluded that for non-financial companies, comprehensive income and net income have equally the same ability to measure a company's performance as the latter neither correlates more strongly with return on share and better predict cash flows compared with the first. Using the phenomenon of IFRS adoption, Doukakis (2010) proved that IFRS adoption requiring presentation of comprehensive income does not improve the persistence of earnings and their components systematically for future profitability. On the contrary, the persistence of both operating and non-operating income decreases, and so does the explanatory power, upon IFRS adoption.

Value relevance is understood as the ability of financial statement information to capture or summarize information that affects share values and empirically tested as a statistical association between market values and accounting values (Hellström, 2006). The proof that net income more persistently and more strongly correlates with return on share and better predicts cash flows (Dhaliwal et al., 1999) indicates that net income is relevant to firm value assessment compared with comprehensive income. Realized gains and losses of AFS securities affect net income to be reported. It means that such gains and losses may affect the firm value as well.

The use of managerial discretion to manage accruals will not affect firm value in the event of constant investment as a result of a reserve element, i.e. the use of an increase in future earnings to cover a decrease in current earnings (Penman, 2013). Based on efficient market assumptions, stock market prices are determined based on assessment results of investors of various information, including financial statements. Thus, earnings management should exercise no effect on firm value. Unfortunately, company investment generally does not stay constant and managers, in addition to their discretion to determine accruals, also exercise discretion to decide real activities. Management of real activities refers to the management of earnings with small reserve due to their transitory nature, thus enabling real earnings management activities to affect firm value. The proof of real activities through the realization of securities gains and losses to manage earnings reported on the banking industry is shown by Shrieves and Dahl (2003), Dantas, De Meideiros, Galdi, \& Da Costa (2013), Barth et al. (2017), and Greiner (2015).

As a signal, realized gains and losses on AFS securities would certainly gain responses from investors at the stock market. Companies with unrealized gains or losses on AFS securities potentially increase or decrease their future earnings, thereby triggering investors to react. However, a company with considerable realized gains on securities will provoke an adverse reaction from investors as they indicate that performance of the company's core operations is not that good and such an attempt must be done in order to increase its earnings or liquidity. Besides, it will lower investors' expectations of future economic prospects as a result of a reduction in the remaining unrealized gains on AFS securities which the company still holds. If banks realize losses on AFS securities and such realization results in a net income reduction, investors will react positively because such net income reduction has no correlation with the performance of its core operations. Such a condition will also reduce any potential losses in the future as unrealized losses on AFS securities have already been realized presently. With less future potential losses, future cash flow is expected to grow as it leads to the increase of financial performance (Mihaela, 2016). Thus, the realization of losses is expected to boost future financial performance so that such a realization will be responded positively, which then results in higher firm value. Based on the foregoing, real activities through realized gains and losses on AFS securities for signaling purposes will provoke investors' negative responses or negatively affect firm value. 
H1: Banks with high realized AFS securities gains (losses) will have low (high) firm value.

\section{METHODOLOGY}

\subsection{Sample selection}

In this study, the data sources were quarterly financial statements and end-quarter stock prices from www.idx.co.id. The sample of the study comprises banking companies listed on the IDX from 2011 to 2017, taken from Fact Books 2012 to 2018. This study employed a purposive sampling method using the following criteria: banking companies listed on the IDX from 2011 until 2017, income statement provided as comprehensive income format, data on realized AFS securities gains and losses were disclosed in the financial statements, and data on the companies' quarterly financial statements and end-quarters stock market prices for the period between 2011 and 2017 could be collected. The reason why the data began in 2011 is that rules on comprehensive income presentation began coming into force in that year.

\subsection{Measurement of variables}

\subsubsection{Dependent variable}

In this study, the dependent variable was firm value, which was measured based on Tobin's $Q$ (TOBIN). TOBIN was measured as the book value of total assets minus the book value of equity added with the market value of equity scaled by the book value of total assets at year-end (Orens, Aerts, \& Lybaert, 2009).

\subsubsection{Independent variable}

The independent variable in this study was realized gains and losses on AFS securities (RGLAFSS), which was measured based on accumulated realized gains and losses on AFS securities deflated by beginning-of-quarter total assets.

\subsubsection{Control variables}

This study used the following control variables: net income before realized AFS securities gains and losses, loss, leverage, size, and growth. Net income before realized AFS securities gains and losses was measured by subtracting net income with realized AFS securities gains and losses. The loss was dummy variable and it equals one if the bank informs realized losses on AFS securities, otherwise, it equals to 0 (Park, 2018). Leverage was measured by dividing total debts by total equity. As leverage rises, it is expected that creditors serve as external monitors that help reduce agency problems, thus facilitating higher firm value (Hassan, Romilly, Giorgioni, \& Power, 2009). Size was measured using the natural logarithm of total assets (Al-Akra \& Ali, 2012). The larger firms have a lower firm value since the activities of these firms are more diversified (Chen, Guo, \& Mande, 2006). Growth was measured by dividing interest income for the current period by interest income in the previous period. The formula above was modified from the ones used by Hassan et al. (2009), who used formula by dividing sales for the current period by sales in the previous period. As data on interest income were obtained from quarterly financial statements, it means that data on interest income in the second quarter was the accumulation of interest income during the first and second quarters, and so on, thus data on interest income were standardized using total assets of the previous period. 
The enormous growth of interest income signifies the rapid growth of dividends in the future, thus facilitating an increase in firm value (Hassan et al., 2009).

\subsection{Multivariate model}

RGLAFSS is the independent variable tested in this research. We predicted that RGLAFSS has a negative coefficient with $\mathrm{p}$ value below 0.05. If so, the hypothesis of this research, i.e banks with high realized AFS securities gains (losses) will have low (high) firm value, is supported. The value of realized gains and losses on AFS securities affects the amount of net income reported. Based on the efficient market hypothesis, investors cannot be tricked by increased or decreased net income due to such gains or losses. They make decisions by taking into account net income before the addition (deduction) of realized gains (losses) on AFS securities. Therefore, the models included the variable net income before RGLAFSS (NI_RGLAFSS). Like Park (2018), the models adopted in this study included the variable LOSS based on prospect theory. According to this theory, the value function has a more dramatic slope in the case of loss compared to the gain of the same amount (Kahneman \& Tversky, 1979). In the context of this study, when realized losses on AFS securities and realized gains on AFS securities have an equal amount, the first will have value relevance higher than that of the latter. From prior researches, leverage (Lev) strongly correlates with firm value. With high leverage, creditors are expected to perform as external monitors to reduce agency problem, resulting in the increase of firm value (Hassan et al., 2009). Larger firms (size) have a lower firm value since the activities of these firms are more diversified (Chen et al., 2006). In terms of growth, more dividend is expected following higher company growth so that the firm value may as well surge (Hassan et al., 2009). Thus, in this study, the proposed models to examine the value relevance of realized gains and losses on AFS securities is:

$$
\mathrm{FV}_{\text {it }}=\alpha_{0}+\alpha_{1} \text { RGLAFSS }_{\text {it }}+\alpha_{2} \text { NI_RGLAFSS }_{\text {it }}+\alpha_{3} \text { LOSS }_{\text {it }}+\alpha_{4} \mathrm{LeV}_{\mathrm{it}}+\alpha_{5} \text { Size }_{\text {it }}+\alpha_{6} \text { Growth }_{\text {it }}+\varepsilon
$$

where $\mathbf{F V}_{\text {it }}$ is the firm value proxy by Tobin's Q (TOBIN) (Orens et al., 2009; Abdullah, Shukor, Mohamed, \& Ahmad, 2015), price-to-book value of equity (PBV) (Abdullah et al., 2015), and market capitalization (MCAP) (Abdullah et al., 2015); RGLAFSS ${ }_{\text {it }}$ is accumulated realized gains and losses on AFS securities scaled with total assets at the beginning of the period (Barth et al., 2017); NI_RGLAFSS it $_{\text {is }}$ accumulated net income before RGLAFSS; LOSS $_{\text {it }}$ is the dummy variable equal to1, if the bank informs realized losses on AFS securities, otherwise it equals to 0 (Park, 2018); Levit is the total debt-to-total asset ratio (Klein, Shapiro, \& Young, 2005; Chen, Guo, \& Mande, 2006), but in this research, total debt is deposits from third

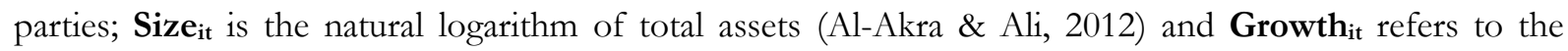
accumulated interest income of the current period scaled with total assets at the beginning of the period divided by the accumulated interest income of the previous period scaled with total assets at the beginning of the period (Hassan et al., 2009; Al-Akra \& Ali, 2012). The hypothesis is approved if $\alpha_{1}$ is significantly negative.

\section{EMPIRICAL RESULTS, ROBUSTNESS TESTS, AND DISCUSSION}

\subsection{Derivation of samples}

Based on the sample-drawing process, there were a total of 443 banks-quarter observations for 26 listed banks as listed in Table 1. 
Derivation of samples

\begin{tabular}{|c|c|c|c|c|}
\hline No. & Description & $\begin{array}{c}\text { Number } \\
\text { of } \\
\text { Banks }\end{array}$ & Calculation & $\begin{array}{l}\text { Number of } \\
\text { Observations }\end{array}$ \\
\hline 1. & Banks listed on the IDX & 43 & $43 \times 4$ quarters $\times 7$ years & 1,204 \\
\hline 2. & $\begin{array}{l}\text { Number of banks not yet listed on the IDX } \\
\text { in } 2011\end{array}$ & 11 & $11 \times 4$ quarters $\mathrm{x} 1$ year & $(44)$ \\
\hline 3. & $\begin{array}{l}\text { Number of banks not yet listed on the IDX } \\
\text { in } 2012\end{array}$ & 8 & $8 \times 4$ quarters $\times 2$ years & (64) \\
\hline 4. & $\begin{array}{l}\text { Number of banks not yet listed on the IDX } \\
\text { in } 2013\end{array}$ & 3 & $3 \times 4$ quarters $\times 3$ years & $(36)$ \\
\hline 5 & $\begin{array}{lll}\text { Income Statements were not } \\
\text { comprehensive. }\end{array}$ & & & $(13)$ \\
\hline 6. & $\begin{array}{l}\text { Information about realized gains and losses } \\
\text { on AFS securities was presented together } \\
\text { with the other securities. }\end{array}$ & & & $(291)$ \\
\hline 7. & $\begin{array}{l}\text { Information about realized gains and losses } \\
\text { on AFS securities was unavailable. }\end{array}$ & & & $(224)$ \\
\hline 8. & Financial statements are unavailable & & & (88) \\
\hline 9. & $\begin{array}{l}\text { Data on end-quarter stock price is } \\
\text { unavailable. }\end{array}$ & & & (1) \\
\hline & Number of observations & & & 443 \\
\hline
\end{tabular}

From the observation period of 2011 to 2017, there should be a sample of 1,204 observations. However, from 2011 to 2013, 22 banks were not yet listed in Indonesia Stock Exchange, thus eliminating 144 observations. Then, 291 observations combined realized gains and losses on AFS securities with those on other securities and 224 observations did not disclose the realized gains and losses on AFS securities. 13 observations were excluded due to non-comprehensive report, 88 observations for the unavailability of financial reports, and 1 other observation owing to the unavailability of the end-quarter stock price. In total, there are 443 observations for this research, of which 197 reported not realizing gains and losses on AFS securities, 192 reported realizing gains on AFS securities, and 54 reported realizing losses on AFS securities.

\subsection{Descriptive statistics}

Table 2 shows descriptive statistics for the variables used in the regression analysis. The average TOBIN's value is 1.0740, which indicates good performance. The average TOBIN's value greater than 1 suggests that the companies' market value exceeds the book value of assets owned by the companies. The average RGLAFSS is very small as 197 of 443 observations reported not realizing gains and losses on AFS securities, meaning that RGLAFSS equals to zero. Likewise, the average NI_RGLAFSS is also so small, i.e. 0.0088 , as on average, the banks' total assets far exceed their net income. The average leverage of 0.6652 indicates that the banks have a moderate level of financial risk. In terms of firm size, on average, sample banks are found to have a total of 31.8525 assets (worth IDR157,718,134 million). The average growth is 1.2879 , meaning that on average, the sample banks underwent growth as indicated by the growth value greater than 1. 
Descriptive Statistics for Variables Used in the Analysis

\begin{tabular}{|l|l|c|c|c|c|c|}
\hline \multicolumn{2}{|c|}{ Variable } & Mean & Median & SD & Minimum & Maximum \\
\hline Firm value (FV) & TOBIN & 1.0740 & 1.0307 & 0.1442 & 0.2110 & 1.8754 \\
\hline & PBV & 1.5533 & 1.2548 & 0.9044 & 0.2495 & 5.7913 \\
\hline $\begin{array}{l}\text { Realized Gain/Loss } \\
\text { on AFS Securities }\end{array}$ & RGLAF & 30.0895 & 30.2917 & 1.5019 & 26.5913 & 33.9124 \\
\hline $\begin{array}{l}\text { Realized Gain/Loss } \\
\text { on AFS Securities } \\
\text { measured with } \\
\text { fractional ranking }\end{array}$ & RGLAFSS_rank & 0.0001 & 0.0000 & 0.0007 & -0.0030 & 0.0063 \\
\hline $\begin{array}{l}\text { Net income before } \\
\text { realized gain/loss on } \\
\text { AFS Securities }\end{array}$ & NI_RGLAFSS & 0.0087 & 0.0085 & 0.0108 & -0.0806 & 0.0424 \\
\hline Leverage & & & & & & 1.0000 \\
\hline Firm size & Lev & 0.6655 & 0.6998 & 0.1222 & 0.2592 & 0.8964 \\
\hline Growth & Size & 31.8532 & 32.0864 & 1.4501 & 28.2997 & 34.6562 \\
\hline Note: $n=443$ & Growth & 1.2883 & 1.3841 & 0.7113 & 0.1516 & 8.0650 \\
\hline
\end{tabular}

Definitions of variables: $\mathbf{F V}_{\mathbf{i t}}$ refers to the firm value proxy by Tobin's Q (TOBIN), price-to-book value of equity

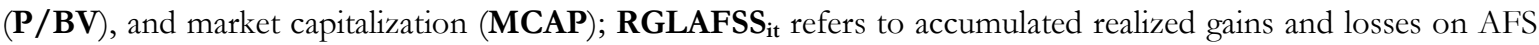
securities scaled with total assets at the beginning of the period; RGLAFSS_rank $\mathbf{k}_{\mathbf{i t}}$ refers to accumulated realized gains and losses on AFS securities were measured using fractional ranking; NI_RGLAFSS it $_{\text {refers to accumulated }}$ net income before RGLAFSS; LOSS $_{\text {it }}$ refers to the dummy variable; equal to 1 if the bank informs realized losses on AFS securities, 0 for otherwise; $\mathbf{L e v}_{\text {it }}$ refers to the deposits from third parties-to-total asset ratio; Size $_{\mathbf{i t}}$ refers to the natural logarithm of total assets; and $\mathbf{G r o w t h}_{\text {it }}$ refers to the accumulated interest income of the current period scaled with total assets at the beginning of the period divided by the accumulated interest income of the previous period scaled with total assets at the beginning of the period.

\subsection{Univariate analysis}

Table 3 shows the results of the Pearson correlation test for RGLAFSS, TOBIN, MCAP, and control variables. Correlations between firm value (TOBIN, PBV, and MCAP) and three control variables (NI_RGLAFSS, Leverage, and Size) are significant, but the other two control variables (Loss and Growth) are less significant. The correlation between NI_RGLAFSS and firm value is significantly positive for all three firm value proxies. The positive correlation between NI_RGLAFSS and firm value suggests that NI_RGLAFSS is related to firm value. It means that to make decisions involving information related to realized AFS securities gains and losses, investors will consider the magnitude of net income before realizing such gains or losses. 
Correlations

\begin{tabular}{|c|c|c|c|c|c|c|c|c|c|}
\hline & TOBIN & PBV & MCAP & $\begin{array}{c}\text { RGLAF } \\
\text { SS }\end{array}$ & $\begin{array}{l}\text { RGLAF } \\
\text { SS_rank }\end{array}$ & $\begin{array}{l}\text { NI_RG } \\
\text { LAFSS }\end{array}$ & LOSS & Lev & Size \\
\hline $\begin{array}{l}\text { PBV } \\
\text { t-stat } \\
\text { p-value }\end{array}$ & $\begin{array}{r}0.8694 \\
36.9602 \\
0.0000\end{array}$ & & & & & & & & \\
\hline $\begin{array}{l}\text { MCAP } \\
\text { t-stat } \\
\text { p-value }\end{array}$ & $\begin{array}{l}0.2254 \\
4.8600 \\
0.0000\end{array}$ & $\begin{array}{l}0.2392 \\
5.1743 \\
0.0000\end{array}$ & & & & & & & \\
\hline $\begin{array}{l}\text { RGLAFSS } \\
\text { t-stat } \\
\text { p-value }\end{array}$ & $\begin{array}{r}-0.0591 \\
-1.2437 \\
0.2143\end{array}$ & $\begin{array}{r}-0.0506 \\
-1.0660 \\
0.2870\end{array}$ & $\begin{array}{r}-0.0551 \\
-1.1596 \\
0.2468\end{array}$ & & & & & & \\
\hline $\begin{array}{l}\text { RGLAFSS_rank } \\
\text { t-stat } \\
\text { p-value }\end{array}$ & $\begin{array}{r}-0.1398 \\
-2.9667 \\
0.0032\end{array}$ & $\begin{array}{r}-0.1595 \\
-3.3942 \\
0.0008\end{array}$ & $\begin{array}{l}0.2337 \\
5.0490 \\
0.0000\end{array}$ & $\begin{array}{l}0.5645 \\
14.361 \\
0.0000\end{array}$ & & & & & \\
\hline $\begin{array}{l}\text { NI_RGLAFSS } \\
\text { t-stat } \\
\text { p-value }\end{array}$ & $\begin{array}{l}0.1628 \\
3.4652 \\
0.0006\end{array}$ & $\begin{array}{l}0.1814 \\
3.8738 \\
0.0001\end{array}$ & $\begin{array}{l}0.3978 \\
9.1074 \\
0.0000\end{array}$ & $\begin{array}{l}0.0521 \\
1.0969 \\
0.2733\end{array}$ & $\begin{array}{l}0.0875 \\
1.8447 \\
0.0657\end{array}$ & & & & \\
\hline $\begin{array}{l}\text { LOSS } \\
\text { t-stat } \\
\text { p-value }\end{array}$ & $\begin{array}{r}-0.0273 \\
-0.5739 \\
0.5663\end{array}$ & $\begin{array}{l}0.0201 \\
0.4241 \\
0.6716\end{array}$ & $\begin{array}{l}0.0727 \\
1.5308 \\
0.1265\end{array}$ & $\begin{array}{r}-0.2640 \\
-5.7479 \\
0.0000\end{array}$ & $\begin{array}{r}-0.5924 \\
-15.4448 \\
0.0000\end{array}$ & $\begin{array}{r}-0.1167 \\
-2.4690 \\
0.0139\end{array}$ & & & \\
\hline $\begin{array}{l}\text { Lev } \\
\text { t-stat } \\
\text { p-value }\end{array}$ & $\begin{array}{l}0.1081 \\
2.2847 \\
0.0228\end{array}$ & $\begin{array}{l}0.1501 \\
3.1903 \\
0.0015\end{array}$ & $\begin{array}{r}-0.1376 \\
-2.9189 \\
0.0037\end{array}$ & $\begin{array}{l}0.1326 \\
2.8113 \\
0.0052\end{array}$ & $\begin{array}{l}0.2288 \\
4.9377 \\
0.0000\end{array}$ & $\begin{array}{r}-0.1307 \\
-2.7695 \\
0.0059\end{array}$ & $\begin{array}{r}-0.1252 \\
-2.6506 \\
0.0083\end{array}$ & & \\
\hline $\begin{array}{l}\text { Size } \\
\text { t-stat } \\
\text { p-value }\end{array}$ & $\begin{array}{r}-0.1343 \\
-2.8460 \\
0.0046\end{array}$ & $\begin{array}{r}-0.1160 \\
-2.4537 \\
0.0145\end{array}$ & $\begin{array}{r}0.9052 \\
44.7467 \\
0.0000\end{array}$ & $\begin{array}{r}-0.0070 \\
-0.1487 \\
0.8818\end{array}$ & $\begin{array}{l}0.3089 \\
6.8225 \\
0.0000\end{array}$ & $\begin{array}{l}0.2974 \\
6.5431 \\
0.0000\end{array}$ & $\begin{array}{l}0.0916 \\
1.9327 \\
0.0539\end{array}$ & $\begin{array}{r}-0.1717 \\
-3.6606 \\
0.0003\end{array}$ & \\
\hline $\begin{array}{l}\text { Growth } \\
\text { t-stat } \\
\text { p-value }\end{array}$ & $\begin{array}{r}-0.0659 \\
-1.3882 \\
0.1658\end{array}$ & $\begin{array}{r}-0.0716 \\
-1.5085 \\
0.1321\end{array}$ & $\begin{array}{r}-0.0203 \\
-0.4266 \\
0.6699\end{array}$ & $\begin{array}{l}0.0256 \\
0.5387 \\
0.5904\end{array}$ & $\begin{array}{l}0.0161 \\
0.3392 \\
0.7346\end{array}$ & $\begin{array}{l}0.1629 \\
3.4681 \\
0.0006\end{array}$ & $\begin{array}{l}0.0330 \\
0.6941 \\
0.4880\end{array}$ & $\begin{array}{r}-0.0072 \\
-0.1526 \\
0.8788\end{array}$ & $\begin{array}{l}0.0062 \\
0.1322 \\
0.8949\end{array}$ \\
\hline
\end{tabular}

Refer to table 2 for definitions of variables.

\subsection{Multivariate analysis}

Table 4 presents the results of hypothesis testing using a regression analysis based on the models of the study. Table 4 and 5 contain the final test result after correction due to issues of heteroscedasticity or autocorrelation or both. The first column presents the independent variable of the study, while the second present the direction of the coefficients as predicted, and third column present results of regression testing using TOBIN as dependent variables. Based on the third column, the regression equations generate a significant F-statistic at 1\%, with adjusted R-squared amounting to 0.0799 . The RGLAFSS coefficients is 16.9700 which is significant at $1 \%$ and the coefficients is according to the expected direction. It means that realized gains and losses on AFS securities negatively affect firm value.

Net income before the addition or deduction of realized gains and losses on AFS securities (NI_RGLAFSS) has a significantly positive effect. It means that net income before realized gains or losses on AFS securities is an important aspect to consider by investors and that realized gains or losses on AFS securities will not trick them into making mistakes, even though such gains or losses can affect the amount of net income reported.

Loss have a significant negative coefficient. It implies that if the bank suffer losses, the firm value decreases as losses are dummy variable scored 1 when present. Leverage has a significant positive value, as 
represented by positive coefficient. The higher the leverage, the higher the firm value. Size was predicted to have a negative influence towards firm value. According to the predicted sign, the test result indicates that size correlates negatively towards firm value. The bigger the company, the lower the firm value. Oppositely, Growth has a significant effect on firm value, but the actual coefficient differs from the expected one. The negative coefficient of growth indicates higher interest income compared to that of the previous period, which reduces firm value.

Table 4

Hypothesis Testing Results

\begin{tabular}{|c|c|c|c|c|}
\hline Model: $\mathrm{FV}_{\mathrm{it}}=\alpha$ & $\iota_{1}$ RGLA & $+\alpha_{2} \mathrm{NI}$ & $\operatorname{LOSS}_{i t}+\alpha_{4} \operatorname{Lev}_{\text {it }}$ & $\mathrm{ze}_{\mathrm{it}}+\alpha_{6}$ Growth $_{\mathrm{it}}+\varepsilon$ \\
\hline Independent & ariable & & ependent variable (FV & \\
\hline & Predicted & TOBIN & PBV & MCAP \\
\hline & Sign & Coefficient (t-stat) & Coefficient (t-stat) & Coefficient (t-stat) \\
\hline Constant & & $1.5870(6.5039)^{* * *}$ & $4.2158(3.2228)^{* * *}$ & $1.1985(1.6991)^{*}$ \\
\hline RGLAFSS $_{\text {it }}$ & - & $-16.9700(-3.4044)^{* * *}$ & $-85.3457(-1.8699)^{*}$ & $-128.9746(-2.9779) * * *$ \\
\hline NI_RGLAFSS & + & $3.4551(5.0812)^{* * *}$ & $24.1558(5.3530) * * *$ & $21.8059(6.2566) * * *$ \\
\hline LOSS $_{\text {it }}$ & - & $0.0076(0.2747)$ & $0.2170(1.6673)^{*}$ & $0.0109(0.1212)$ \\
\hline $\mathrm{Lev}_{\text {it }}$ & + & $0.1434(2.2987)^{* *}$ & $1.2951(3.5926) * * *$ & $0.4838(2.6340)^{* * *}$ \\
\hline Size $_{\text {it }}$ & - & $-0.0191(-2.8447) * * *$ & $-0.1116(-3.0160)^{* * *}$ & $0.8957(42.5122)^{* * *}$ \\
\hline Growth $_{\text {it }}$ & + & $-0.0212(-2.2994) * *$ & $-0.1491(-2.6099) * * *$ & $-0.1047(-2.7811)^{* * *}$ \\
\hline $\mathrm{N}$ & & 443 & 443 & 443 \\
\hline Adjusted $\mathrm{R}^{2}$ & & 0.0799 & 0.1007 & 0.8425 \\
\hline F-statistic & & $7.4030 * * *$ & $9.2501 * * *$ & $395.0733 * * *$ \\
\hline
\end{tabular}

Notes: statistically significant at $* 10, * * 5$, and $* * * 1$ percent.

Refer to table 2 for definitions of variables.

Hypothesis testing results presented in table 4 show that the model have an F-statistic less than 1\%, which suggests that independent variables in the model managed to explain the variable firm value. However, consistent with the purpose of this study, i.e. to examine the effect of realized AFS securities gains and losses on firm value, the model managed to prove that realized gains or losses on AFS securities affect firm value.

\subsection{Robustness Tests}

Robustness tests were conducted to test the research model using different measurement, i.e. 1) firm value was measured using Price-to-Book value (PBV) and Market Capitalization (MCAP). According to (Abdullah et al. (2015), PBV can indicate whether the market value of the company is higher or lower than its book value of equity. MCAP was employed as well due to its accuracy in measuring firm value. It takes into account the overall market value of a company, whereas the stock price only measures firm value based on a single stock price (Anam, Fatima, \& Majdi, 2011; Uyar \& K1lıc, 2012). The result of the tests is displayed in the fourth and fifth column of table 4. 2) Realized gains and losses on AFS securities were measured using fractional ranking. The method was used as a measurement alternative as RGAFSS data may carry positive and negative values, with wide gap in between. Fractional ranking eliminates the negative value, yet the lowest value remains. It is measured by sorting and ranking the data from the smallest to the highest value. The rank is then divided by the total number of observation, so that the biggest value of the data is 1 . 
This method was also employed by Tucker \& Zarowin (2006) in income smoothing. The result of robustness tests is presented in table 5 .

Robustness Test Results

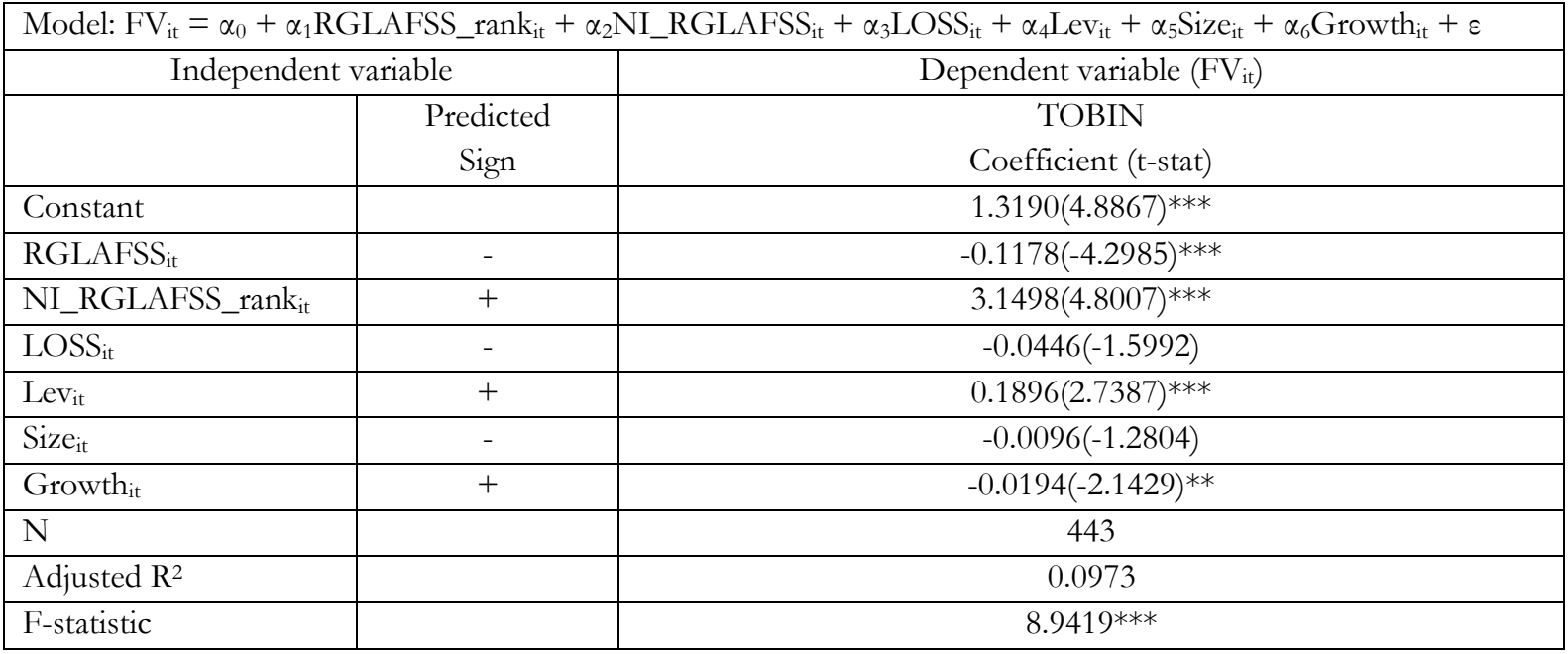

Notes: statistically significant at $* 10, * * 5$, and $* * * 1$ percent.

Refer to table 2 for definitions of variables.

\subsection{Discussion}

In table 4 , the third and fourth columns provide results of regression testing using two different dependent variables, i.e. PBV and MCAP. Two regression equations generate a significant F-statistic at 1\%, with adjusted R-squared of 0.1007 and 0.8425 , respectively. The RGLAFSS coefficients of the two equations are negative, according to the expected direction. The RGLAFSS coefficient with dependent variables PBV equals to -85.3457 , significant at $10 \%$. Likewise, the equations with dependent variable MCAP, with coefficients of -128.9746 , show the significant effect at $1 \%$. In table 5 , when realized gains and losses on AFS securities are measured using fractional ranking, RGLAFSS_rank significantly correlates negatively, that is -0.1178 at $1 \%$ against firm value. It means that realized gains and losses on AFS securities negatively affect firm value.

The robustness test in table 4 is also in conformity with the correlation between variable TOBIN-PBV and TOBIN-MCAP. Both indicate strong correlation with the value of 0.8694 and 0.2254 (table 3), significant at $1 \%$. By so, the firm value can be measured using one of those three sizes. Similar condition is found in variables RGLAFSS and RGLAFSS_rank. The correlation of both is 0.5645 , also significant at $1 \%$ (Table 3). Therefore, the result in table 5 suggests consistent result that the realized gains and losses on AFS securities negatively influences firm value.

The finding supports Barth (1994) which attests that the realized gains and losses from investment securities negatively correlates with stock return. Nevertheless, this fact is not solely correlated with AFS securities, but also investment securities. This finding is opposite to Yousefinejad et al. (2017) who instead discovered value relevance of the unrealized gains and losses on AFS securities. 


\section{CONCLUSION, LIMITATION, AND FUTURE RESEARCH DIRECTION}

Examining the usefulness of reporting comprehensive income as a result of the enactment of the accounting standard PSAK No. 1 (2009) is expected to contribute to the development of positive and normative accounting theories. Determining value relevance is a way to examine the usefulness of particular information for users. Numerous tests on the value relevance of earnings information have been carried out. This study examined value relevance of realized gains and losses on AFS securities. Realized gains and losses on AFS securities may affect the amount of net income reported in comprehensive income presentation. As it proves true that net income has fairly high-value relevance compared to other earnings information, it means that realized gains or losses on AFS securities may affect firm value.

Results of this study demonstrate that banks with high realized AFS securities gains (losses) will have low (high) firm value. Moreover, it can also be interpreted that realized gains and losses on AFS securities negatively affect firm value. It means that users of financial statements have considered realized gains and losses on AFS securities when they get information about net income. Realized gains on AFS securities that increase net income will provoke negative responses. This finding shows that users understand that the resulting net income does not result from core banking operations. Conversely, banks realizing losses on AFS securities trigger positive responses among users of financial statements as the resulting losses do not result from their core operations, but from other operations (non-interest income). Furthermore, the results of this study also tend to corroborate findings that banks diversifying into non-interest income activities run a higher risk.

This study has several limitations. First, it did not limit the realized gains and losses on AFS securities to one type of realization activity only, for example sales of AFS securities, because it collect information about realized gains and losses of AFS securities from several sources in financial statements, which were notes to the financial statements on sales of AFS securities, reclassification of AFS securities in the income statements, and adjustment to unrealized gains or losses on AFS securities in the notes to the financial statements. Second, this research used the end-quarter stock price instead of the stock price at the publication of the quarterly report. Third, the results of this study cannot be generalized to non-banking companies. AFS securities are owned not only by banks but also by companies running a business in other sectors. To conclude, future research is expected to examine the effect of realized gains and losses on AFS securities on firm value with improvement to the limitations above. First is testing the influence of the realized gains and losses on AFS securities towards the firm value, for example only the groups of realized gains and losses caused by the sale of such securities. This is feasible to see further whether different realization of gains and losses will incline towards different response. Second is using the stock price at the publication or a certain period of time after publication to observe the response time over the information about the realized gains and losses of AFS securities (Boulland et al., 2019). Third is the use of non-bank institutions for the sample. However, AFS securities is part of financial assets commonly hold by banks. Therefore, the realized gains and losses of AFS securities in non-bank institutions can be expanded into their non-main operation activities. It is intended to examine whether such activities in such institutions have a value relevance.

\section{ACKNOWLEDGEMENT}

The authors would like to express their gratitude to the Doctoral Dissertation Research Grant of Indonesian Ministry of Research, Technology and Higher Education for the financial support to carry out this research. 


\section{REFERENCES}

Abdullah, M., Shukor, Z. A., Mohamed, Z. M., \& Ahmad, A. (2015). Risk Management Disclosure: A Study on The Effect of Voluntary Risk Management Disclosure toward Firm Value. Journal of Applied Accounting Research, 16(3), 400-432. https://doi.org/10.1108/JAAR-10-2014-0106

Aboody, D., \& Lev, B. (1998). The Value Relevance of Intangibles: The Case of Software Capitalization. Journal of Accounting Research, 36, 161-191. https://doi.org/10.2307/2491313

Ahmed, A. S., \& Takeda, C. (1995). Stock Market Valuation of Gains and Losses on Commercial Banks' Investment Securities an Empirical Analysis. Journal of Accounting and Economics, 20(2), 207-225. https://doi.org/10.1016/0165-4101(95)00396-Z

Al-Akra, M., \& Ali, M. J. (2012). The Value Relevance of Corporate Voluntary Disclosure in The Middle-East: The Case of Jordan. Journal of Accounting and Public Policy, 31(5), 533-549. https://doi.org/10.1016/j.jaccpubpol.2011.10.007

Anam, O. A., Fatima, A. H., \& Majdi, A. R. H. (2011). Effects of Intellectual Capital Information Disclosed in Annual Reports on Market Capitalization Evidence from Bursa Malaysia. Journal of Human Resource Costing \& Accounting, 15(2), 85-102. https://doi.org/10.1108/14013381111157328

Barth, M. E. (1994). Fair Value Accounting: Evidence from Investment Securities and the Market Valuation of Banks. The Accounting Review, 69(1), 1-25. Retrieved from http://www.jstor.org/stable/248258

Barth, M. E., Gomez-Biscarri, J., Kasznik, R., \& López-Espinosa, G. (2017). Bank Earnings and Regulatory Capital Management Using Available for Sale Securities. Review of Accounting Studies, 22, 1761-1792. https://doi.org/10.1007/s11142-017-9426-y

Bian, W., \& Wang, X. (2015). Non-interest Income, Profit, and Risk Efficiencies: Evidence from Commercial Banks in China. Asia-Pacific Journal of Financial Studies, 44, 762-782. https://doi.org/10.1111/ajfs.12112

Biddle, G. C., \& Choi, J.-H. (2006). Is Comprehensive Income Useful? Journal of Contemporary Accounting \& Economics, 2(1), 1-32. https://doi.org/10.1016/S1815-5669(10)70015-1

Black, D. E. (2016). Other Comprehensive Income: A Review and Directions for Future Research. Accounting \& Finance, 56(1), 9-45. https://doi.org/10.1111/acfi.1218

Boulland, R., Lobo, G. J., \& Paugam, L. (2019). Do Investors Pay Sufficient Attention to Banks ' Unrealized Gains and Losses on Available-for-sale Securities? European Accounting Review, 28(5), 819-848. https://doi.org/10.1080/09638180.2018.1562950

Casabona, P. A., \& Conville, T. (2014). Statement of Comprehensive Income: New Reporting and Disclosure Requirements. Review of Business, 35(1), 23-34.

Chambers, D., Linsmeier, T. J., Shakespeare, C., \& Sougiannis, T. (2007). An Evaluation of SFAS No. 130 Comprehensive Income Disclosures. Review of Accounting Studies, 12, 557-593. https://doi.org/10.1007/s11142007-9043-2

Chen, C. R., Guo, W., \& Mande, V. (2006). Corporate Value, Managerial Stockholdings and Investments of Japanese Firms. Journal of International Financial Management and Accounting, 17(1), 29-51. https://doi.org/10.1111/j.1467646X.2006.00120.x

Dantas, J. A., De Meideiros, O. R., Galdi, F. C., \& Da Costa, F. M. (2013). Securities-Based Earnings Management in Banks: Validation of a Two- Stage Model. Revista Contabilidade \& Finanças, 24(61), 37-54. https://doi.org/10.1590/S1519-70772013000100005

DeYoung, R., \& Roland, K. P. (2001). Product Mix and Earnings Volatility at Commercial Banks: Evidence from a Degree of Total Leverage Model. Journal of Financial Intermediation, 10, 54-84. https://doi.org/10.1006/jfin.2000.0305

Dhaliwal, D., Subramanyam, K. R., \& Trezevant, R. (1999). Is Comprehensive Income Superior to Net Income as A Measure of Firm Performance? Journal of Accounting and Economics, 26, 43-67. https://doi.org/10.1016/S01654101(98)00033-0

Dinh, T., Kang, H., \& Schultze, W. (2016). Capitalizing Research \& Development: Signaling or Earnings Management? European Accounting Review, 25(2), 373-401. https://doi.org/10.1080/09638180.2015.1031149

Doukakis, L. C. (2010). The Persistence of Earnings and Earnings Components after The Adoption of IFRS. Managerial Finance, 36(11), 969-980. https://doi.org/10.1108/03074351011081286 
Fan, Q. (2007). Earnings Management and Ownership Retention for Initial Public Offering Firms: Theory and Evidence. The Accounting Review, 82(1), 27-64. https://doi.org/4. https://doi.org/10.2308/accr.2007.82.1.27

Feltham, G. A., \& Ohlson, J. A. (1995). Valuation and Clean Surplus Accounting for Operating and Financial Activities. Contemporary Accounting Research, 11(2), 689-731. https://doi.org/10.1111/j.1911-3846.1995.tb00462.x

Financial Accounting Standard Board. 1984. Statement of Financial Accounting Concepts No. 5. Connecticut: Financial Accounting Standard Board.

Financial Accounting Standard Board. 2011. Accounting Standards Update (ASU) No. 2011-05, Comprehensive Income (Topic 220): Presentation of Comprehensive Income. Connecticut: Financial Accounting Standard Board.

Greiner, A. J. (2015). The Effect of The Fair Value Option on Bank Earnings and Regulatory Capital Management: Evidence from Realized Securities Gains and Losses. Advances in Accounting, Incorporating Advances in International Accounting, 31(1), 33-41. https://doi.org/10.1016/j.adiac.2015.03.005

Hartnett, N. (2010). The Value Relevance of Earnings Forecast Disclosures: An Investigation of Forecast Attributes and Signalling in The Australian IPO context. Applied Financial Economics, 20, 1819-1828. https://doi.org/10.1080/09603107.2010.526574

Hassan, O. A. G., Romilly, P., Giorgioni, G., \& Power, D. (2009). The Value Relevance of Disclosure: Evidence from The Emerging Capital Market of Egypt. The International Journal of Accounting, 44(1), 79-102. https://doi.org/10.1016/j.intacc.2008.12.005

Hellström, K. (2006). The Value Relevance of Financial Accounting Information in a Transition Economy: The Case of the Czech Republic. European Accounting Review, 15(3), 325-349. https://doi.org/10.1080/09638180600916242

Hirst, D. E., \& Hopkins, P. E. (1998). Comprehensive Income Reporting and Analysts 'Valuation Judgments. Journal of Accounting Research, 36, 47-75. https:/ / doi.org/DOI: 10.2307/2491306

Hsiao, H.-F., Liao, S.-L., Su, C.-W., \& Sung, H.-C. (2017). Product Market Competition. R \& D Investmen Choice, and Real Earning Management. International Journal of Accounting and Information Management, 25(3), $296-312$. https://doi.org/10.1108/IJAIM-06-2016-0067

Ikatan Akuntan Indonesia. 2012. Standar akuntansi keuangan. Jakarta: Ikatan Akuntan Indonesia.

Jaggi, B., \& Zhao, R. (2002). Information Content of Earnings and Earnings Components of Commercial Banks: Impact of SFAS No. 115. Review of Quantitative Finance and Accounting, 18, 405-421. https://doi.org/10.1023/A:1015457804420

Kabir, M. H., \& Laswad, F. (2011). Properties of Net Income and total Comprehensive Income: New Zealand Evidence. Accounting Research Journal, 24(3), 268-289. https://doi.org/10.1108/10309611111187000

Kahneman, D., \& Tversky, A. (1979). Prospect Theory: An Analysis of Decision Under Risk. Econometrica, 47(2), 263291.

Klein, P., Shapiro, D., \& Young, J. (2005). Corporate Governance, Family Ownership and Firm Value: The Canadian Evidence. Corporate Governance an International Review, 13(6), 769-784. https://doi.org/10.1111/j.14678683.2005.00469.x

Leland, H. E., \& Pyle, D. H. (1977). Information Asymmetries, Financial Structure, and Financial Iintermediation. The Journal of Finance, 32(2), 371-387. https://doi.org/10.1111/j.1540-6261.1977.tb03277.x

Lepetit, L., Nys, E., Rous, P., \& Tarazi, A. (2008). Bank Income Structure and Risk: An Empirical Analysis of European Banks. Journal of Banking \& Finance, 32, 1452-1467. https://doi.org/10.1016/j.jbankfin.2007.12.002

Lev, B., \& Zarowin, P. (1999). The Boundaries of Financial Reporting and How to Extend Them. Journal of Accounting Research, 37(2), 353-385. https://doi.org/10.2469/dig.v30.n3.702

Lin, S. W., Ramond, O. J., \& Casta, J.-F. (2007). Value Relevance of Comprehensive Income and Its Components: Evidence from Major European Capital Markets. Unpublished Paper. Universite of Paris Dauphine, Paris, France.

Maines, L. A., \& McDaniel, L. S. (2000). Effects of Comprehensive-Income Characteristics on Nonprofessional Investors' Judgments: The Role of Financial-Statement Presentation Format. Accounting Review, 75(2), $179-207$. https://doi.org/10.2308/accr.2000.75.2.179

Mihaela, S. (2016). The Competition between London Companies Regarding Their Financial Performance. Journal of Competitiveness, 8(2), 5-16. https://doi.org/10.7441/joc.2016.02.01 
Mita, A. F., Siregar, S. V. N. P., \& Fitriany (2017). Income (OCI) in Indonesia. International Journal of Applied Business and Economic Research, 15(20), 133-152.

Morris, R. D. (1987). Signalling, Agency Theory and Accounting Policy Choice. Accounting and Business Research, 18(69), 47-56. https://doi.org/10.1080/00014788.1987.9729347

Orens, R., Aerts, W., \& Lybaert, N. (2009). Intellectual Capital Disclosure, Cost of Finance and Firm value. Management Decision, 47(10), 1536-1554. https://doi.org/10.1108/00251740911004673

Park, H. (2018). Market Reaction to Other Comprehensive Income. Sustainability, 10(6), 1-14. https://doi.org/10.3390/su10061837

Penman, S. H. (2013). Financial Statement Analysis and Security Valuation (5th ed.). New York: McGraw-Hill.

Scott, W. R. (2015). Financial Accounting Theory (7th ed.). Toronto: Pearson Canada Inc.

Shrieves, R. E., \& Dahl, D. (2003). Discretionary Accounting and The Behavior of Japanese Banks Under Financial Duress. Journal of Banking \& Finance, 27, 1219-1243. https://doi.org/10.1016/S0378-4266(02)00252-2

Titman, S., \& Trueman, B. (1986). Information Quality and the Valuation of New Issues. Journal of Accounting and Economics, 8(2), 159-172. https://doi.org/10.1016/0165-4101(86)90016-9

Tong, Y. H., \& Miao, B. (2011). Are Dividends Associated with the Quality of Earnings? Accounting Horizons, 25(1), 183-205. https://doi.org/10.2308/acch.2011.25.1.183

Tucker, J. W., \& Zarowin, P. a. (2006). Does Income Smoothing Improve Earnings Informativeness ? The Accounting Review, 81(1), 251-270. https://doi.org/10.2308/accr.2006.81.1.251

Uyar, A., \& K1lic, M. (2012). Value Relevance of Voluntary Disclosure: Evidence from Turkish Firms. Journal of Intellectual Capital, 13(3), 363-376. https://doi.org/10.1108/14691931211248918

Vermaelen, T. (1981). Common Stock Repurchases and Market Signalling An Empirical Study. Journal of Financial Economics, 9(2), 139-183. https://doi.org/10.1016/0304-405X(81)90011-8

Warfield, T. D., \& Linsmeier, T. J. (1992). Tax Planning, Earnings Management, and the Differential Information Content of Bank Earnings Components. The Accounting Review, 67(3), 546-562. Retrieved from http://www.jstor.org/stable/247977 .

Yousefinejad, M., Ahmad, A., \& Embong, Z. (2017). Value Relevance of Other Comprehensive Income and Its Available-For-Sale Financial Instruments ( AFS ) and Revaluation Surplus of Property, Plant and Equipment ( REV ) Components. Asian Journal of Accounting and Governance, 8, 133-143. https://doi.org/10.17576/AJAG2017-08SI-12 